\title{
ОСОБЛИВОСТІ ЕКОНОМІЧНОЇ ПОВЕДІНКИ ДОМОГОСПОДАРСТВА ЯК ВІДКРИТОЇ СОЦІАЛЬНО-ЕКОНОМІЧНОЇ СИСТЕМИ
}

\author{
Роман Іванов, кандидат фізико-математичних наук, доиент \\ Україна, Дніпро, Дніпровський наџіональний університет імені Олеся Гончара
}

DOI: https://doi.org/ 10.31435/rsglobal_ws/30122018/6271

\begin{tabular}{l} 
ARTICLE INFO \\
Received: 25 October 2018 \\
Accepted: 19 December 2018 \\
Published: 30 December 2018 \\
\hline KEYWORDS \\
households, \\
economic behavior of households, \\
organization, \\
self-organization, \\
reflection, \\
socio-economic system..
\end{tabular}

\section{ARTICLE INFO}

Received: 25 October 2018

Accepted: 19 December 2018

\section{KEYWORDS}

economic behavior of households, organization,

socio-economic system..

\begin{abstract}
At macro and microeconomic levels, household behavior is usually analyzed within the framework of such basic concepts: neoclassicism, institutionalism, and behaviorism.

It is noted that a household is a socio-economic object, which has such properties as integrity, hierarchy, integrability, openness, heterogeneity. The research analyzes the peculiarities of the economic behavior of a household as an open socio-economic system, which is formed on the macro level on the principles of organization and self-organization, and at the macro level, quasi-organization, self-organization and selfreflection.

In this case, there are natural manifestations of a reflexive approach in cases where relations between elements of the socio-economic system are not relations of direct subordination.

The indirect impact on the household's economic behavior on the part of the state is to translate the motives for decision-making. After all, reflexive management in contrast to the organization does not involve the presence of direct commands, instructions, demonstration of the pattern of behavior, but consists in the transfer of incentives for the desired solutions.

At the same time, households can not only perceive differently the controlling influence, but also generate solutions that are not desirable from the standpoint of the state economy, which is multiplied in the conditions of the socio-economic crisis.
\end{abstract}

Citation: Роман Іванов. (2018) Osoblyvosti Ekonomichnoi Povedinky Domohospodarstva yak Vidkrytoi Sotsialno-Ekonomichnoi Systemy. World Science. 12(40), Vol.2. doi: 10.31435/rsglobal_ws/30122018/6271

Copyright: (C) 2018 Роман Іванов. This is an open-access article distributed under the terms of the Creative Commons Attribution License (CC BY). The use, distribution or reproduction in other forums is permitted, provided the original author(s) or licensor are credited and that the original publication in this journal is cited, in accordance with accepted academic practice. No use, distribution or reproduction is permitted which does not comply with these terms.

Вступ. Час та розвиток економічної науки впливають на підходи та методи дослідження економічних процесів. Адже розвиток наукового бачення в цілому та накопичення статистичної інформації, отриманою на основі багаторічних спостережень, дозволяють виділити загальні принципи та закономірності розвитку економічних систем та процесів, які протікають в них або породжуються ними [1], змінюючи таким чином, коли це можливо, рівень інформаційної ентропії.

При цьому, однією з методологічних проблем сучасної економічної науки є проблема формалізації, яка протиставляється змістовному та інтуїтивному економічному мисленню та пов'язана, перш за все, з математизацією економічних знань, яка передбачає як простіший кількісний аналіз первинної економічної інформації, так й створення комплексів складних багаторівневих формально-математичних моделей та теорій [2].

Завданням економіко-математичного моделювання, як розділу економічної науки $\epsilon$ побудова та дослідження економіко-математичних моделей та їх практичне застосування. 
Адже, це теоретична наука, безпосереднім предметом дослідження якої $\epsilon$ економікоматематичні моделі, а непрямим - економічні явища, процеси та об'єкти, формалізований опис яких дозволяє узагальнено формулювати базові теоретичні положення та отримувати на їх основі практичні висновки [3].

У цьому контексті моделювання є одним з актуальних напрямів економічної науки, тісно пов’язаним з обгрунтуванням стратегії економічної поведінки та способів ії реалізації.

Результати дослідження. На сучасному етапі розвиток теорії та методології економікоматематичного моделювання слід вбачати залучення досягнень такого напрямку філософії, як феноменологічний підхід, який грунтується на паралельному розвитку досліджуваного об' єкту, свідомості суб'єкту пізнання та методу, за допомогою якого суб'єкт пізнає об'єкт [4].

Разом 3 цим процес пізнання явищ навколишньої дійсності дозволяє виявити не лише об'єктивні, але й суб'єктивні передумови використання понять, пов'язаних 3 неповнотою наявних відомостей про об'єкт пізнання, з виникаючими в ході цього процесу помилками та ін. Адже саме розуміння таких категорій, як визначеность і невизначеність, співвідношення між ними істотно змінювалось на різних етапах розвитку наукового знання. Так, Л. М. Гутнер вбачає певний синонімічний зв'язок поняття визначеність і таких аспектів буття, як стійкість, необхідність, дискретність, відносна ізольованість і ін., а невизначеність - 3 такими, як становлення, взаємодія, безперервність, випадковість і т. п. Г5].

Першим та найбільш важливим етапом економіко-математичного моделювання $\epsilon$ постановка проблеми та ії якісний аналіз, який, зокрема, передбачає разом з вибором об'єкту та мети дослідження визначення критеріїв досягнення цієї мети. Так, для дослідження економічної поведінки домогосподарств можна застосовувати аналіз домогосподарства як елементу системи та як самостійної системи із застосуванням засобів структуризації [6].

При цьому, об’єктна структуризація застосовується до домогосподарства, як до організаційного елементу економічної системи, створюваною функціонуванням та взаємодією індивідуумів, а процесуальна - відображає функціонування домогосподарства як суб'єкту, представленого сукупністю пов'язаних процесів [7].

Таким чином, домогосподарство як суб'єкт економічної системи є самостійним учасником економічних процесів, діяльність якого спрямована на задоволення потреб його членів шляхом реалізації основних функцій, а домогосподарство як самостійна система $\epsilon$ місцем неперервного відтворення економічних ресурсів. Отже в залежності від місця домогосподарства в ієрархічній структурі досліджуваної системи невизначеність в процесі моделювання економічної поведінки має різний механізм та, відповідно, різні форми прояву.

У сучасній економічній теорії існують різні дефініції економічної системи. Але кожна 3 них так чи інакше узгоджується із спільними рисами загального поняття «системи», до яких слід віднести: структурованість об'єкту; наявність структурних зв’язків між елементами; властивість, яка відображає специфіку взаємодії елементів системи та ідентифікує систему в цілому [8].

Отже, з точки зору системоутворення економічна система $є$ сукупністю економічних елементів, які утворюють цілісну економічну структуру суспільства, єдність взаємовідносин, які виникають в процесі виробництва, розподілу, обміну та споживання [9].

Дещо інакше трактується економічна система в роботі [10], в якій вона визначається як сукупність усіх видів людської діяльності в процесі виробництва, обміну, розподілу та споживання, а також регулювання такої діяльності. Більш детальний підхід до розуміння суті економічної системи виявляє С. В. Мочерний, визначаючи іiі як комплекс підсистем та елементів, що взаємодіють, сукупність економічних зв'язків між ними, наслідком чого $є$ виникнення законів розвитку та функціонування даної системи, які представляють ії цілісність та організованість, посилюючи ефективність досягнення загальної економічної мети [11].

Основою виникнення та існування економічної системи слід вважати іiї цілісність, яка полягає у стійкій економічні взаємодії їі елементів [12]. При цьому, М. Атанов наголошує, що економічна система - це «спільнота елементів та підсистем, об'єднаних функціональними горизонтальними зв’язками» [13], які передбачають відношення щодо операцій обміну результатами діяльності елементів системи. А процес взаємодії елементів економічної системи породжує певні явища, які можна розглядати як модель поведінки системи в різних умовах іiі функціонування [8].

Отже, можна говорити, що економічна система - це сукупність економічних відносин між суб'єктами, що хазяйнують і здійснюють вибір способів оптимального використання обмежених ресурсів з метою задоволення індивідуальних і суспільних потреб, забезпечення 
регулярної циркуляції продукту виробництва в національному масштабі та створення умов життєздатності системи, ії саморегулювання та розвитку [12].

Увагу дослідників зосереджено на економічній поведінці домогосподарств, фірм, державних органів на різних ринках, які $\epsilon$ місцем реалізації видів, мотивів, особливостей економічної поведінки [14]. Але, саме домогосподарства слід вважати первинним елементом економічної системи, саме домогосподарства $є$ головним джерелом інвестування та стимулювання розвитку реального сектора економіки [15]. Домашні господарства $\epsilon$ власниками значної частки ресурсів та «виробниками» людського капіталу, вони формують споживчий попит на ринку товарів та послуг, а також пропозицію на ринку праці [16]. Домогосподарство та його дохід безпосередньо беруть участь у всіх трансформаційних процесах, що відбуваються в соціально-економічній системі суспільства, впливають на динаміку й тенденції розвитку економіки [17].

При цьому, аналіз місця домогосподарства в суспільній економіці дозволяє робити наступні висновки [12]:

- домогосподарство є основним суб’єктом національної економіки, поєднуючи в собі формальні та неформальні типи економічної поведінки; основним мотиваційним фактором функціонування домогосподарства $€$ створення та підтримка умов нормальної (задовільної) життєдіяльності шляхом виконання основних функцій;

- основним продуктом і товаром домогосподарства є робоча сила;

- як споживач домогосподарство повинно мати джерело благ для задоволення власних потреб;

- кожному етапу суспільного розвитку відповідає певна організаційна форма домогосподарства;

- в традиційній економічній системі економічна поведінка домогосподарств грунтується на системі правил, звичок, життєвому укладі в різних умовах.

При цьому, як на макро- так і на мікроекономічному рівні поведінка домогосподарств зазвичай аналізується у межах таких основних концепцій: неокласицизму, інституціоналізму та біхевіоризму.

Так, неокласична економічна теорія певним чином ототожнює домогосподарство 3 родиною як виробничою одиницею, функціонування якої спрямоване на максимізацію добробуту його членів шляхом оптимізації витрат часу, що витрачається як на працю всередині домашнього господарства так і на ринку праці. До того ж ту чи іншу роботу виконує той, хто здатен це зробити найбільш раціонально в економічному розумінні [18].

На сьогодні неокласика вважається економічним мейнстримом для якого актуальною залишається абстракція «економічної людини». 3 огляду на раціональність економічної поведінки домогосподарства це передбачає максимізацію вигоди та мінімізацію витрат, що забезпечується наступними припущеннями [19]:

- суб’єкт є незалежним (рішення приймаються самостійно, виходячи з власних інтересів);

- суб'єкт є егоїстичним (основною задачею є турбота про власні інтереси, а метою максимізація власної вигоди);

- суб'єкт є раціональним (на шляху досягнення мети обирається найбільш зручна або вигідна альтернатива);

- суб'єкт є інформованим (достатньо інформації як про власні потреби, так і про можливі варіанти їх задоволення).

Так, повністю узгоджуються 3 принципом егоїстичності ординалістська теорія корисності та стандартна теорія вибору споживача Ф. Еджуорта, В. Парето, І. Фішера, Р. Аллена, Дж. Хікса; існування загальної економічної рівноваги в інтерпретації Ерроу-Дебре; теорія виявлених вподобань І. Бентама, М. Ріхтера, А. Сена.

Але дійсність $є$ такою, що в прийнятті рішень індивід покладається не лише на розум, але й на інтуїцію, а мотивація його економічної поведінки формується також неекономічними факторами [20]. Зокрема, модель А. Сена передбачає врахування таких зовнішніх факторів, як моральні принципи та загальнолюдські норми.

На противагу раціональності економічної поведінки пропонуються ймовірнісні моделі К.Ерроу, Неймана-Моргенштерна, Ф. Найта. В моделях Бруннера-Меклінга та 3. Лінденберга, які разом 3 максимізацією корисності передбачають певну обмеженість, пов'язану із суб'єктивними оцінками, очікуваннями та вибором, робляться спроби поєднання рис економічної поведінки в межах неокласичного та інституціонального підходів.

Адже інституціональний напрямок враховує в якості факторів формування економічної поведінки домогосподарств соціально-статеву нерівність всередині господарства, концепцію родини, демографічний фактор та ін. [12]. Враховуючи вплив позаекономічних (соціально- 
психологічних) факторів, які пояснюють економічну поведінку домогосподарств, представники інституціонального підходу не вважають еквівалентними такі поняття як «домогосподарство» та «індивід», але погоджуються 3 тим, що домогосподарство, як основна економічна одиниця, яка приймає рішення, є групою індивідів, яка й утворює суспільне господарство. Крім того, домогосподарство є суб'єктом, що існує в певному інституціональному середовищі, яке й визначає структуру домогосподарства, внутрішні відносини між його членами та, як наслідок, його ендогенне середовище 「16].

Важливими характеристиками екзогенних факторів, які впливають на формування загальної мети господарській діяльності домогосподарства та множини варіантів її досягнення, слід вважати невизначеність станів соціального та інституціонального середовища, масштабність та складність інформації, що в окремих випадках унеможливлює ії сприйняття, аналіз та використання. Саме це, на думку Дж. Ходжсона, зумовлює виникнення ситуацій, в яких домогосподарство не може бути оптимізатором, а сам процес оптимізації стає окремим випадком широкого класу задач прийняття рішень. Таким чином, інституціональний підхід $\epsilon$ основою для розуміння поведінкової передумови - обмеженої раціональності, яка передбачає дискримінацію вибору за рахунок впливу трансакційних витрат [21].

В цей же час, представники неоінституціонального підходу Р. Коуз, Д. Нортон, О. Уільямсон, Г. Беккер та ін. пов'язують існування домогосподарства 3 його здатністю до зменшення трансакційних витрат, що забезпечується за рахунок стандартних зразків та практики поведінки в родині [22].

Серед представників біхевіористської економіки виділимо роботи нобеліатів Дж. Акерлофа та Р. Шиллера, які висунули теорію «ірраціонального початку», що передбачає психологічні та соціальні фактори впливу на формування економічної поведінки людини, Д. М. Фаддена, який пов'язує основи неокласичної моделі поведінки економічних агентів 3 генетичними основами людської психології, теорію перспектив Д. Канемана та А. Тверскі, яку сучасники цілком справедливо вважають показовим прикладом сумісного використання психологічних та економічних досліджень.

Окремі біхевіористичні риси можна виявити в основних принципах еволюційної економіки, сформульованих Р. Нельсоном та С. Уінтером. Так основними поведінковими передумовами еволюційної теорії можна вважати: обмежену раціональність, гетерогенність, генотипичну спадковість, змінність та економічний відбір.

Отже, домогосподарство є соціально-економічним об'єктом, якому притаманні такі властивості, як цілісність, ієрархічність, інтегративність, відкритість, неоднорідність.

Крім того, як відзначав автор фундаментальних праць 3 теорії управління В.М. Глушков, економічній системі притаманні такі риси, як організованість, цілеспрямованість та керованість, під якою слід розуміти сукупність об'єктивних i суб'єктивних чинників, що забезпечують або намагаються забезпечити іï рівновагу чи функціонування в певному режимі. Так, чинниками економічного процесу слід вважати умови, в яких або завдяки яким даний процес протікає. До того ж доцільно вирізняти чинники зростання та чинники розвитку, перші з яких у першу чергу впливають на нарощування кількісних параметрів, а другі - на якісні показники [1].

Слід також відзначити, що необхідним фактором ефективного функціонування економічної системи є процес його регулювання, а серед основних типів такого регулювання виділяють: державне регулювання, ринкове саморегулювання та змішане (ринково-державне) регулювання [10].

3 огляду на моделювання економічної поведінки домогосподарства як відкритої соціально-економічної системи слід згадати, що у широкому сенсі під поняттям «організація» розуміють сукупність процесів та дій, що спрямовані до виникнення та вдосконалення зв'язків між елементами цілого та інтеграцію їх в систему [23].

Якщо розглядати процес організації з точки зору способів досягнення впорядкованості системи, то виділяються, 3 одного боку, зовнішні фактори впливу, а 3 іншого - взаємодія виключно іiі внутрішніх складових. У першому випадку йдеться про регульовану організацію 3 метою створення, формування певної системи, у другому - про її самоорганізацію [24].

Отже, основними відмінностями між організацією і самоорганізацією є те, що „в межах самоорганізації відповідна організація досягається завдяки внутрішнім факторам і відбувається ніби сама по собі, організацію завжди хтось або щось здійснює або направляє” Ґ25].

Враховуючи вищезазначене, можна визначити самоорганізацію, як здатність системи самостійно (без спрямованого зовнішнього впливу) реалізовувати процеси, що забезпечують іiі функціонування та розвиток [26]. 
В роботах А.В. Бакурової [27, 28], присвячених дослідженню концепції моделювання самоорганізації соціально-економічних систем, проводиться семантичний аналіз слова «самоорганізація» і відзначається, що приставка «само-» позначає іманентність причин явища, тобто дії виконуються без зовнішнього втручання завдяки властивості, що притаманна предмету за його природою. Там же відзначається, що така приставка має характеризувати дію об'єкта, яка спрямована на самого себе.

3 огляду на такий підхід можна припустити, що економічна поведінка домогосподарства, як відкритої соціально-економічної системи, спрямована на забезпечення життєдіяльності в умовах існуючого середовища завжди є самоорганізацією.

Але, порівнюючи властивості організації та самоорганізації, в роботі [27] відзначається, зокрема, що організаційні процеси виникають як результат попереднього плану та завжди існує суб'єкт їх виникнення; метою процесу є досягнення системою стану, структура якого відома до його реального втілення.

3 цієї точки зору в межах неокласичної теорії можна говорити, що самоорганізації всередині домогосподарства, спрямованій у першу чергу на зростання, притаманні риси організаційних процесів, коли в умовах раціональності прийняття рішення домогосподарство стає як об'єктом так і свідомим суб’єктом. Тому вважаємо коректним називати таку економічну поведінку домогосподарства «квазіорганізацією».

Намагаючись внести ясність в суть поняття самоорганізації в соціально-економічній системі, автор робіт $[27,28]$ дає таке трактування - це процес управління системою на основі синергетичного підходу, що полягає в забезпеченні їі життєздатності, тобто умов існування та розвитку. При цьому, процеси та відповідні ним структури виникають не заплановано, а аналогом мети системи є атрактор, що забезпечує іiі здатність до розвитку та стійкість при взаємодії із зовнішнім середовищем Г29†.

Слід також відзначити, що у соціально-економічних системах процеси організації та самоорганізації можуть відбуватися одночасно, а їх нетривіальні композиції $\epsilon$ основою розвитку таких систем [27].

Таким чином, при дослідженні домогосподарства як елемента системи (макрорівень) слід погодитись 3 тим, що організаційна роль у цьому випадку може належати лише цілеспрямованим діям елементу вищого рівня, який контролює, регулює або створює умови, в яких (до яких) функціонує (адаптується) домогосподарство.

Так, саме держава за допомогою як економічних, так і адміністративно-правових методів регулює (організовує) економічну поведінку домогосподарства в умовах відповідного забезпечення доходів у формі заробітної платні, соціальної допомоги та соціальних трансфертів і створює умови, адаптація (самоорганізація) до яких дозволяє домогосподарству отримувати прибуток і змішаний дохід, дохід від власності.

Самоорганізація домогосподарств в таких умовах $\epsilon$ елементом ринкового саморегулювання, одним 3 основних методів якої є збалансування попиту і пропозиції на продукти та ресурси і, як наслідок, встановлення ринкових цін на них.

Окремі особливості регулювання приватного сектору, до якого належать домогосподарства, наведені в таблиці 1.

Таблиця 1. Особливості регулювання приватного сектору економіки [авторська розробка]

\begin{tabular}{|c|c|}
\hline \multicolumn{2}{|c|}{ Типи управління економічної поведінки домогосподарства на макрорівні } \\
\hline Організація & Самоорганізація \\
\hline $\begin{array}{c}\text { Адміністративне (державне) } \\
\text { регулювання }\end{array}$ & Ринкове саморегулювання \\
\hline \multicolumn{2}{|c|}{ Домінуюча економічна теорія } \\
\hline Кейнсіанська теорія & Класична та неокласична теорія \\
\hline \multicolumn{2}{|c|}{ Основна мета } \\
\hline $\begin{array}{c}\text { Створення умов для підтримки } \\
\text { рівноваги }\end{array}$ & $\begin{array}{c}\text { Рівновага між попитом та пропозицією, } \\
\text { оптимізація розподілу ресурсів }\end{array}$ \\
\hline \multicolumn{2}{|c|}{ Характер економічної поведінки домогосподарства } \\
\hline Пасивний & Активний \\
\hline
\end{tabular}

Якщо ж досліджувати домогосподарство як самостійну систему (мікрорівень), то державу слід вважати зовнішнім середовищем, а його дії (бездіяльність) - інтегральним екзогенним фактором (сигналом). 
Опосередкований вплив на економічну поведінку домогосподарства 3 боку держави полягає у трансляції мотивів прийняття рішень. Адже, рефлексивне управління на відміну від організації не передбачає наявності прямих команд, вказівок, демонстрації шаблону поведінки, а полягає в передачі стимулів для виникнення бажаних рішень.

При цьому домогосподарства можуть не лише по різному сприймати керуючий вплив, а й генерувати рішення не бажані з точки зору державної економіки, що мультиплікується в умовах соціально-економічної кризи. Окремі поведінкові стратегії у цьому випадку можуть залежати від індивіда, його пам'яті, досвіду, асоціацій, інституціональних особливостей домогосподарства та формуватись на принципах стадної поведінки [30].

Проведений аналіз дозволив автору виділити низку особливостей економічної поведінки домогосподарства на мікрорівні, які наведені в таблиці 2.

Таблиця 1. Особливості управління економічною поведінкою домогосподарства як відкритої соціально-економічної системи [авторська розробка]

\begin{tabular}{|c|c|c|c|}
\hline Типи управління & Квазіорганізація & Самоорганізація & Саморефлексія \\
\hline Підхід до управління & Кібернетичний & Синергетичний & Рефлексивний \\
\hline $\begin{array}{c}\text { Домінуюча } \\
\text { економічна теорія }\end{array}$ & Неокласична теорія & Інституціоналізм & Біхевіоризм \\
\hline Мета & Зростання & Рівновага & Рівновага \\
\hline $\begin{array}{c}\text { Особливості } \\
\text { поведінки }\end{array}$ & Раціональність & $\begin{array}{c}\text { Обмежена } \\
\text { раціональність }\end{array}$ & $\begin{array}{c}\text { Ірраціональність або } \\
\text { ситуативна } \\
\text { раціональність }\end{array}$ \\
\hline Координація & $\begin{array}{l}\text { На рівні } \\
\text { вертикальних } \\
\text { зв'язків }\end{array}$ & $\begin{array}{l}\text { На рівні } \\
\text { горизонтальних } \\
\text { зв'язків }\end{array}$ & $\begin{array}{l}\text { На рівні } \\
\text { опосередкованих } \\
\text { зв'язків }\end{array}$ \\
\hline Дії в умовах кризи & $\begin{array}{l}\text { Збільшення доходів } \\
\text { за рахунок ділової } \\
\text { активності }\end{array}$ & $\begin{array}{l}\text { Реструктуризація } \\
\text { витрат за рахунок } \\
\text { корегування } \\
\text { споживання }\end{array}$ & $\begin{array}{l}\text { реструктуризація цілей } \\
\text { та зміна правил }\end{array}$ \\
\hline
\end{tabular}

Висновки. В представленому дослідженні зроблена спроба аналізу особливостей економічною поведінкою домогосподарства як відкритої соціально-економічної системи, яка на макрорівні формується на принципах організації та самоорганізації, а на макрорівні квазіорганізації, самоорганізації і саморефлексії.

При цьому, природним є прояви рефлексивного підходу у випадках, коли відносини між елементами соціально-економічної системи не є відносинами прямого підпорядкування.

Опосередкований вплив на економічну поведінку домогосподарства 3 боку держави полягає у трансляції мотивів прийняття рішень. Адже, рефлексивне управління на відміну від організації не передбачає наявності прямих команд, вказівок, демонстрації шаблону поведінки, а полягає в передачі стимулів для виникнення бажаних рішень.

При цьому домогосподарства можуть не лише по різному сприймати керуючий вплив, а й генерувати рішення не бажані $з$ точки зору державної економіки, що мультиплікується в умовах соціально-економічної кризи.

\section{ЛIТЕРАТУРА}

1. Белова Н. П. Управление экономическими системами: теоретические подходы / Н. П. Белова, Г. В. Калинина, А. М. Калинин // Вестник ЧГУ. - №4. - 2009. - С.58-67.

2. Овчаров А. О. Экономическая методология и проблема формализации в экономике / А. О. Овчаров // Актуальные проблемы экономики и права. - №1. - 2013. - С. 10-16.

3. Технические системы : (Процессы, конструкции, эффективность) / Амиров Р. Я., Гареев Р. Г., Глазунов В. И. [и др.]; Акад. наук Респ. Башкортостан. Отд-ние химии; Под общ. ред. Я. С. Амирова и Р. Г. Шарафиева. - Уфа : Гилем, 2000. - 600 с.

4. Гумеров М. Ф. Феноменологический подход в методологии современного экономикоматематического моделирования // Интеграл. - 2014. - №1. - С.72-77.

5. Гутнер Л. М. Философские аспекты измерения в современной физике/ Л. М. Гутнер. - Л.: Изд-во ЛГУ, 1978. - $136 \mathrm{c.}$

6. Нуреев Р. М. Экономические субъекты постсоветской России / Р.М. Нуреев. - М.: Моск. Общий научный фонд, 2003. - 320 с. 
7. Иванова Н. А. Теоретические подходы к исследованию домохозяйства как экономического субъекта / Н. А. Иванова // Вестник Огу. - №13. - 2011. - С. 197-201.

8. Булахова Е. И. К вопросу о понятии «экономическая система» и ее классификации / Е. И. Булахова // Теоретичні і практичні аспекти економіки та інтелектуальної власності. - 2013. - Вип. 2(1). - С. 238-244.

9. Нуреев Р. Курс микроэкономики : [Учебник для ВУЗов] / Нуреев Р.М. - М. : Издательство Норма, 2002. $-572 \mathrm{c}$.

10. Башнянин Г. И. Регулирования экономических систем и его типы / Г. И. Башнянин // Научный вестник. - 2007. - № 17.2. - С. 135-142.

11. Мочерный С. В. Политическая экономия : [учебн. пособ.] / Мочерный С. В. - М. : Пресс, 2002. - 687 с.

12. Петухова Е. П. Институт домашнего хозяйства и его эволюция // Современные проблемы науки и образования. 2014. №2. [Електронний ресурс]. доступу:http://cyberleninka.ru/article/n/institut-domashnego-hozyaystva-i-ego-evolyutsiya

13. Атанов Н. И. Экономическая система: особенности функционирования / Н. И. Атанов, А. А. Лапинская. - Улан-Удэ: БГУ, 1998. - 116 с.

14. Іващенко М. В. Інституціональні характеристики споживчої поведінки домогосподарств на українському ринку в умовах кризових явищ в економіці / М. В. Іващенко // Вісник уні- верситету банківської справи національного банку України. - № 3(12), - 2001. - С. 70 - 73.

15. Ломачинська I. А. Формування фінансової поведінки вітчизняних домогосподарств в сучасних умовах розвитку наці- ональної економіки / I. А. Ломачинська // Вісник Хмельницького національного університету. - № 3. - Т.1. - 2011. - С. 172 - 174.

16. Попов М. В. Домохозяйство как экономический субъект и социально-экономический институт / М.В. Попов // Известия ВГПУ. - 2012. - №9. - С.138-141.

17. Шаманська О. Прагматика реалізації дохідної поведінки домогосподарства в контексті сучасних тенденцій / О. Шаманська // Галицький економічний вісник. - № 1(40). - 2013. - С. 112 - 118.

18. Беккер, Г. Теория распределения времени. Серия «Вехи экономической мысли». Т.З./Г. Беккер/Под ред. В.М. Гальперина. СПб.: Экономическая школа, 2000.

19. Любченко В. С. Экономическое поведение: методология социологического исследования / В. С. Любченко // Теория и практика общественного развития. 2007. №2. URL: http://cyberleninka.ru/article/n/ekonomicheskoe-povedenie-metodologiya-sotsiologicheskogoissledovaniya (дата обращения: 18.01.2017).

20. Орлова И.Ю. Рациональность как черта экономического поведения индивида / И.Ю. Орлова // Социально-политические науки. - №3. - 2014. - С.60-65.

21. Ходжсон Дж. Экономическая теория и институты: манифест современной институциональной экономической теории / Дж. Ходжсон. - М.: Дело, 2003. - 464 с.

22. Беккер Г. Экономика семьи и макроповедение / Г. Беккер // США. Экономика, политика, идеология. - 1994. - №2. - С. 99-107.

23. Социологический энциклопедический словарь / под ред. Г. В. Осипова. - М. : Издательская группа ИНФРА-М-НОРМА, 1998. - 468 с.

24. Кірієнко О.М. Самоорганізація і організація як основи механізму координації економічних систем / О. М. Кірієнко, Г. М. Пилипенко // Науковий вісник Національного університету ДПС України (економіка, право). - 2009. - №4(47) . - С. 24-30.

25. Рузавин Г. И. Самоорганизация как основа организации общественных систем / Г. И. Рузавин // Вопросы экономики. - 1996. - №3. - С.103-114.

26. Мельник Л. Г. Закономірності функціонування та розвитку соціально-економічних систем / Л. Г. Мельник // Актуальні проблеми економіки. - 2010. - № 6(108). - С.41-46.

27. Бакурова А. В. Концепція моделювання самоорганізації соціально-економічних систем / А. В. Бакурова // Держава та регіони. - 2010. - №2. - С. 21-28.

28. Бакурова А. В. Семантичне моделювання процесів самоорганізації в соціальноекономічних системах [Електронний ресурс] / А. В. Бакурова // Проблеми системного підходу в економіці. - К. : Національний авіаційний університет, 2010. - № 1. - Режим доступу: http://www.nbuv. gov.ua/ejournals/PSPE/index.html.

29. Моделювання структури життєздатних соціально-економічних систем : монографія / [Л. Н. Сергєєва, А. В. Бакурова, В. В. Воронцов, С. О. Зульфугарова]. - Запоріжжя : Вид-во КПУ, 2009. - $256 \mathrm{c}$.

30. Рефлексивные процессы в и управление в экономике: концепции, модели, прикладные аспекты: моногр. / Р. Н. Лепа, С. Н. Шкарлет и др.; под ред. Р. Н. Лепы / НАНУ, Ин-т экономики пром-сти. Донецк: АПЕКС, 2013. - 272 c. 